\title{
Vehicle repair shop behaviour on waste management as government policy direction in Makassar City
}

\author{
Sunardi \\ Department of Automotive Engineering Education, \\ State University of Makassar, \\ Campus of Parangtambung, \\ Dg. Tata Raya, Makassar, Indonesia \\ Email: sunardi5510@yahoo.co.id
}

\begin{abstract}
This study aims to determine the effect of education, knowledge, and compliance with environmental regulations on the motivation and behaviour of the manager of a workshop on environmental sanitation in the City of Makassar. The population in this study is the whole workshop managers in the City of Makassar, as much as 343 units. Sample workshop manager assigned 200 people spread across 14 districts. We collect data using questionnaires. Data were analysed using structural equation modelling (SEM). The results showed that the variables of education, knowledge, and adherence have direct and significant impact on motivation. Likewise, education and adherence variables have direct and significant impact on the behaviour of the p-value $>$ 0.05 , but the knowledge variable has no direct influence on behaviour. Variables of education and knowledge have indirect influence through variable between motivation on behaviour.
\end{abstract}

Keywords: behaviour; motivation; vehicle shop.

Reference to this paper should be made as follows: Sunardi (2016) 'Vehicle repair shop behaviour on waste management as government policy direction in Makassar City', Int. J. Environmental Policy and Decision Making, Vol. 2, No. 1, pp.69-74.

Biographical notes: Sunardi over the last ten years has gained experience in automotive education engineering as a lecturer and researcher. Following his studies in automotive engineering at Teacher Training Institutes and Science Education (IKIP), he completed his Master's in Environmental Education at the State University of Makassar, and also his Doctoral program in Environmental Education at State University of Makassar, Indonesia.

\section{Introduction}

High population growth is the reason for the Indonesian Government to build the industrial sector as an option. One of them is the workshop industry who is required to meet the needs of the economy, employment, service to the community, and environmental conservation business [Elliott, (2005), p.7]. Joinery industry development has both positive and negative impacts on the environment. The negative impacts are in the form of pollution, environmental degradation, and damage to the environment [Zhao, (2010), p.112]. This is caused by less serious repair shop managers who do the handling 
of waste generated, either solid, liquid waste, or waste gas (Sunardi, 2009). The impact that arises is environmental issues, and health is the increasing number of patients with acute respiratory tract infections (Soedono, 2001).

According to Salikin (2003, p.5), managing the activities of motor vehicle repair business is not easy because of environmental various problems such as the quality of human resources and the effect on natural resources. Indonesia produces about $23,630,748$ tons of used oil each year, which indicated one gallon of used oil can contaminate one million gallons of drinking water (Media Data Research, 2009). Furthermore, David (2009) said used oil, mercury, cadmium, and lead is used in many industrial processes, but once used is usually thrown away. Then random emissions test in Makassar identified $90 \%$ of urban public transport in critical condition because all parameter emissions testing is not ideal (Department of Transportation, 2009), due to aging vehicles, types of engines, as well as due to lack of maintenance and repair of vehicle engines (Sunardi and Mandra, 2011).

Makassar City with an area of $175.77 \mathrm{~km}^{2}$ and population of 1,352,136 inhabitants, and growth rate of $1.65 \%$ per year, have 1.625 million motor vehicles with a growth rate of $12 \%$ per year, not including vehicles coming from the nearby district town (Central Bureau of Statistics, 2012). There are 343 units of workshops which perform maintenance and repair of motor vehicles that allegedly pollute the environment in the middle of the average population density - average 7,693 people per spread in 14 subdistricts and 143 villages. This condition causes people to be vulnerable to health problems (Wisnu, 2009).

Residential areas around the repair shop tends to decrease the quality of the environment from any waste such as washing liquid waste, solid waste, and gases pollution. Workshop manager seem to have little motivation on the cleanliness of the environment around the shops so there is a tendency for pollution to increase. It is necessary to do a study based on behaviour of repair shop managers in waste management.

Environmental factors around the garage become a factor that can influence the behaviour of the motor vehicle repair shop manager. Direct or indirect influence at responsible environmental behaviour are the knowledge about the issue, acting skills, the desire to act, situational factors such as economic and social, personality such as attitudes, locus of control and individual responsibility. Then, theory of reasoned action (Fishbein and Ajzen, 1975) has been used by researchers to examine the relationship between attitudes, subjective norms, intentions, and behaviour. Also, the planned behaviour theory can be used to predict whether a person will perform or not perform a behaviour.

Attitude is a settled way of thinking or feeling about someone or something, typically one that is reflected in a person's behaviour (Allport, 1954). Subsequently, Mulyadi (2011) says the urgency of the motivation is to create a spirit in the workshop environmental cleaning.

Compliance is according to the rules of behaviour and discipline. Some of the variables that affect the level of compliance by Ferdinand (2007) are: demographics such as age, sex, socio-economic and educational. While the factors that influence non-adherence by Nur (2004) are understanding, quality of interaction, social isolation, and beliefs. According to Oskamp and Wesley Schultz (2005), a variety of strategies to improve adherence are: professional support a workshop manager, social support, and behaviour clean. 
According to Yustina (2006), education is believed to be very influential on the skills, behaviours and attitudes. Knowledge is construction (formation) itself (Von Glasersfeld, 1996). Knowledge consists of three domains, namely cognitive, affective and psychomotor.

Various aspects are considered to influence the behaviour of waste management such as education, environmental knowledge, obedience to environmental regulations, and motivation on environmental cleanliness.

Based on the explanation above, the problem in this research is to determine the effect of education, knowledge of pollution control and compliance with environmental regulations on the motivation and behaviour of environmental management by the workshop manager.

\section{Research methods}

This study includes quantitative research to know the influence of education, knowledge of pollution and compliance with the environmental regulations, the motivation on the cleanliness of the environment, and further acknowledge its influence on behaviour in environmentally waste management. The population in this study totalling 343 units are scattered workshops in 14 districts in the City of Makassar. Samples were determined using proportional sampling method, amounted to $58.31 \%$ of each district with a total sample of 200 general managers of motor vehicle repair shops, which was chosen as respondents.

The variables in this study are all assumed to be homogeneous, in which all independent variables have been linked directly or indirectly to the dependent variable. Thus, the relationship between variables is described in the study design (Figure 1).

Figure 1 Relationships between variables

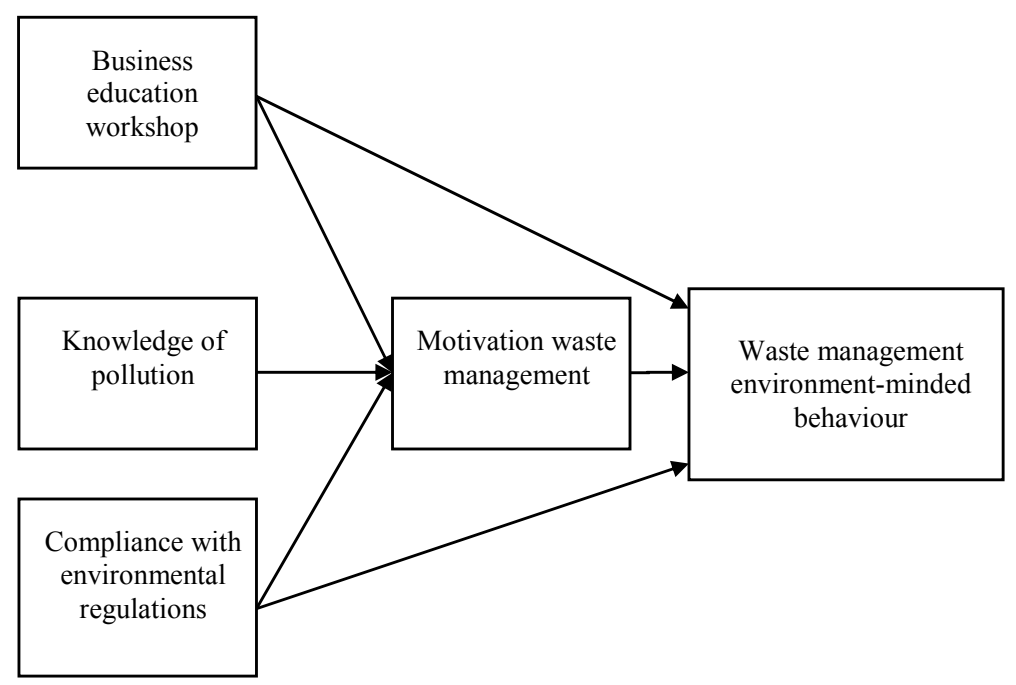

Source: Results synthesis theory, created for research purposes 
Data was collected by questionnaire, documentation and observation, as well as the focus group discussion (FGD) and in-depth interviews involving all stakeholders and experts in the field of environment. The results of data processing, FGD and interview interpreted using structural equation modelling (SEM) analysis with the help of software AMOS 6.0.

\section{Results and discussion}

\subsection{Results}

After going through all the requirements of SEM, such as testing assumptions, goodness of fit tests, then comes the inference analysis or analysis of the structural model that is essentially a hypothesis testing in this study. There are two types of effects that will be tested in the structural model, namely direct effect, and the indirect influence (indirect effect).

Hypothesis testing was done by testing the critical ratio (CR) of direct influence in each direct effect partially. If $\mathrm{CR}>1.96$ or $\mathrm{p}<0.05$, then we can conclude there is a significant effect, on the contrary if the value $\mathrm{CR}<1.96$ or $\mathrm{p}$-value $>0.05$ then we can conclude there is no influence. Detailed results of the analysis contained in the results of SEM analysis. Table 1 presents the results of hypothesis testing of directly influence (direct effect).

Table 1 Regression weights

\begin{tabular}{lccccc}
\hline & Estimate & S.E. & C.R. & $P$ & Label \\
\hline Motivation <--- Education & 0.278 & 0.087 & 3.191 & 0.001 & par_1 \\
Motivation <--- Knowledge & 0.357 & 0.160 & 2.241 & 0.025 & par_3 \\
Motivation <--- Compliance & 0.354 & 0.071 & 5.027 & $* * *$ & par_7 \\
Behaviour <--- Education & 1.489 & 0.113 & 0.13 .150 & $* * *$ & par_2 \\
Behaviour <--- Motivation & 0.214 & 0.085 & 2.52 & 0.012 & par_4 \\
Behaviour <--- Knowledge & -0.085 & 0.196 & -0.434 & 0.664 & par_6 \\
Behaviour <--- Compliance & -0.314 & 0.093 & -3.374 & $* * *$ & par_8 \\
\hline
\end{tabular}

Table 2 Standardised regression weights

\begin{tabular}{lc}
\hline & Estimate \\
\hline Motivation <--- Education & 0.206 \\
Motivation <--- Knowledge & 0.145 \\
Motivation <--- Compliance & 0.325 \\
Behaviour <--- Education & 0.637 \\
Behaviour $<---$ Motivation & 0.123 \\
Behaviour $<---$ Attitude & 0.233 \\
Behaviour $<---$ Knowledge & -0.020 \\
Behaviour $<---$ Compliance & -0.166 \\
\hline
\end{tabular}

From Table 2, it can be analysed that the variables of education, knowledge and adherence variable have direct and significant impact on motivation. This is shown by the significant value of $\mathrm{p}$-value $(0.001,0.025,0.00)$ of $<0.05$. Variable compliance education has direct and significant impact on behaviour. This is shown by the significant value of 
$p$-value $(0: 00,0: 00)$ of $<0.05$. Motivation variable has direct and significant impact on behaviour. It is also demonstrated by the significant value of p-value $(0.012)$ of $<0.05$. While the variable knowledge has no direct and significant impact on behaviour. This is shown by the significant value of $p$-value $(0664)>0.05$.

Next, the complete test results of indirect effect is presented in Table 3.

Table 3 Standardised indirect effects

\begin{tabular}{lcccc}
\hline & Compliance & Knowledge & Education & Motivation \\
\hline Motivation & 0.000 & 0.000 & 0.000 & 0.000 \\
Behaviour & 0.102 & 0.054 & 0.101 & 0.000 \\
\hline
\end{tabular}

From Table 3, it can be seen that there is indirect influence between variable adherence to the behaviour of 0.102 , variable knowledge of the behaviour of 0.054 and education variables on the behaviour of 0.101 . This means that there is a direct positive influence between the variables of obedience, knowledge, and education on behaviour.

\subsection{Discussion}

Based on the results of SEM analysis of the structural model, the relationship repair shop manager education, knowledge of pollution and compliance with environmental regulations to environment motivation are $0.278,0.357,0.354$, with the value of the CR of 3.191, 2.241, 5.027 and probability $(\mathrm{P})$ of $0.001,0.025,0.000$. Because CR $>1.96$, and a $\mathrm{p}$-value of $<0.05$, so it can be explained that there is a significant direct influence of educational manager, knowledge of pollution and compliance with environmental regulations to environmental motivation.

The coefficient of direct influence of educational workshop manager, knowledge of pollution and compliance with environmental regulations to motivation on environmental behaviour is a positive sign which is equal to $0.206,0.145$, and 0.325 . This indicates the influence of education workshop manager, knowledge of pollution and compliance with environmental regulations on environmental hygiene to motivation is positive. That is, the higher the education of the manager of the workshop, knowledge of pollution and compliance with environmental regulations, the higher the motivation on environmental cleanliness.

The magnitude of the relationship between motivation on the environmental hygiene behaviour in environmentally sound waste management is at 0.214 with the value of the CR of 2.521 and the probability (p) of 0.012 . Because CR $>1.96$, and p-value of $<0.05$, it can be explained that there is a significant direct effect on the motivation of the environmental hygiene behaviour in environmentally sound waste management. The direct effect coefficient on the motivation of the environmental behaviour in environmentally waste management has a positive sign. This indicates a direct effect on the motivation of the environmental hygiene behaviour in environmentally sound waste management is positive for 0.123 . That is, the higher the motivation on the cleanliness of the environment, the higher the behaviour in environmentally sound waste management.

\section{Conclusions}

Based on the results and the above discussion, it can be concluded that: 
1 There is a significant and positive direct influence of education, knowledge, and motivation to environmentally waste management, then there is a positive and significant direct influence of education, compliance to environmental policy, and motivation to environmental behaviour, but there is no direct influence on the behaviour of waste management. In addition to direct effects, there are also indirect effects of education, knowledge, and motivation to conduct compliance through environmentally sound waste management.

2 The higher the education, knowledge, adherence to the rules and motivation, the higher the behaviour in environmentally sound waste management.

\section{References}

Allport, G.W. (1954) Hand Book of Social Psychology, Addison Wesley Publishing Company, Cambridge.

Central Bureau of Statistics (2012) Makassar in 2012. Figures, BPS, Makassar.

David, W.T.A. (2009) Workshop Ecological Sciences, Gramedia, Jakarta.

Department of Transportation (2009) Exhaust Emission Test Vehicle in Makassar, Transportation, Makassar.

Elliott, J.A. (2005) An Introduction to Sustainable Development, 3rd ed., Simultaneously published in the USA and Canada by Routledge 270 Madison Ave, 10016, New York, NY.

Ferdinand, A. (2007) Research Methods in Management, Agency Publisher Diponegoro University, Semarang.

Fishbein, M. and Ajzen, I. (1975) Belief, Attitude, Intention and Behavior: An Introduction to Theory and Research, Addison-Wesley, Reading, MA.

Media Data Research (2009) About the Collection of Used Oil, Airlangga University Press, Surabaya.

Mulyadi, N. (2011) 'Effect of environmental knowledge, local wisdom, locus of control and farming motivation on responsible environmental behavior of farmers in Soppeng Regency of South Sulawesi', International Journal of Academic Research, March, Part 1, Vol. 3, No. 2 , pp.171-177.

Nur, M.N. (2004) Transportation Management, Ghalia Indonesia, Jakarta.

Oskamp, S. and Wesley Schultz, P. (2005) Attitudes and Opinions, Lawrence Erlbaum Associates, Mahwah, New Jersey.

Salikin, K.A. (2003) Sustainable Agriculture Systems, Canisius, Yogyakarta.

Soedono, M. (2001) Air Pollution (Collection of Scientific Works), ITB Publishers, Bandung.

Sunardi, N. (2009) Environmental Preservation Through Waste Management Car Repair in Makassar, PPs UNM.

Sunardi and Mandra, P.A. (2011) Correlation of knowledge, Attitude and Behavior Society in Environmental Management, Research Report, Makassar.

Von Glasersfeld, E. (1996) 'Introduktion aspects of constructivism', in Coscot, C. (Ed.): Constructivism, Theory, Perspectives, and Practice, Longman, New York.

Wisnu, W.A. (2009) Impact of Environmental Pollution, Andi, Yogyakarta.

Yustina, P.S. (2006) 'Environmental science relations with perception, attitudes and interests in environmental management at the Primary School Teachers in Pekan Baru', Biogenesis Journal, Vol. 2, No. 2, pp.70-78, FKIP Biology Education Studies University of Riau.

Zhao, J. (2010) Ecological and Environmental Science \& Technology in China: A Roadmap to 2050, Springer-Heidelberg, Dordrecht, London, New York. 